\title{
Development of Low-Resolution, Low-Power and Low-Cost Infrared System
}

\author{
Sebastian Urbaś, Bogusław Więcek \\ Lodz University of Technology, Institute of Electronics, Wólczańska 211/215, 90-924 Łódź, Poland
}

\begin{abstract}
The article presents the construction of a thermal imaging camera with low power consumption. The $80 \times 80$ Micro80Gen2 microbolometric array of detectors records infrared radiation in the LWIR spectral range (long infrared wave, $8-12 \mu \mathrm{m}$ ). The entire digital part of the electronic circuit has been integrated within the reprogrammable FPGA chip from the Spartan 6 family. In order to read and display thermograms, an application for the .NetFremework 3.1 platform, which implements non-uniformity correction (NUC) and image processing, is written. Due to its low cost, small size and weight, the camera can be used in various applications, e.g. in unmanned aerial vehicles (UAV) known as drones.
\end{abstract}

Keywords: bolometer detector, thermographic camera, system development, FPGA

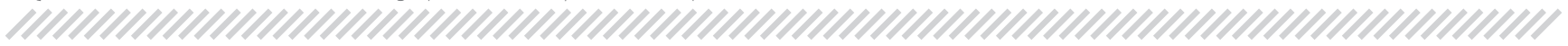

\section{Introduction}

Nowadays, infrared thermography is becoming more and more popular and used in various fields of application, such as environmental protection, civil engineering, medicine, space, military and science. This is the result of significant advances in semiconductor technology leading to low noise, highly integrated and energy efficient integrated circuits.

The field of application seems to be unlimited, as each object at a temperature above $0 \mathrm{~K} \approx-273{ }^{\circ} \mathrm{C}$ emits electromagnetic radiation $[1-4,7,8]$. Normally observed images are viewed in the visible spectrum due to the phenomena of reflection and light scattering. Often however, more interesting and useful is additional information about objects obtained in the "invisible" band of electromagnetic radiation $[3,4]$. Such radiation is infrared radiation, which constitutes a small part of the electromagnetic wavelength $1<\lambda<10^{3} \mu \mathrm{m}[1-4]$. The human eye itself, unlike the detector of a thermal imaging camera, is not able to detect, let alone measure the wavelengths of radiation.

An infrared detector is the main element of a thermal imaging camera. The presented project uses a microbolometric detector operating in the LWIR spectral range, made of amorphous silicon $(a-S i)$. Currently, there are also other detectors available. Among them there are photon detectors operating in low temperature, in many cases in a cryogenic environment [2]. Until 2000, only detectors cooled with liquid nitrogen cooling, Peltier systems and a Stirling pump were produced. In thermal ima-

\section{Autor korespondujący:}

Sebastian Urbaś, seurbas@gmail.com

\section{Artykuł recenzowany nadesłany 31.05.2021 r., przyjęty do druku 28.06.2021 r.}

ging cameras, the optical system should only absorb the infrared radiation, while preventing the visible light from being transmitted to the further part of the system. In IR thermography, germanium, silicon or artificial-material lenses, such as GASIR, are used [1-4].

Initially, thermal imaging devices were used primarily in the army. Currently, IR thermography is widely used in building construction, power engineering, industry, medicine, rescue, facility protection and military. Using thermal imaging cameras, it is possible to monitor objects that are distant, inaccessible and in a dangerous environment, e.g. in a poisonous or explosive atmospheres [1, 4].

Along with the development of electronics, both detector and computer, began to be built cameras that are light, easy to use and with better and better parameters, an example of which is the thermal imaging detector - Micro80Gen2 ${ }^{1}$. The development of microelectronics was greatly influenced by Jack Kilby, an employee of Texas Instrument who built the first integrated circuit. Since then, there has been a dynamic development in electronics [6]. More and more advanced integrated circuits began to emerge. Undoubtedly, one of them is the FPGA, which is used as the main logic element of a thermal imaging camera. The first FPGA chip, which was created in 1985, had only 64 programmable cells (LE). Modern digital reprogrammable FPGAs from the Xilinx Virtex 5, 6, 7 family, or Altera Stratix IV and Stratix V contain hundreds of thousands of reconfigurable logic cells [5]. Special hardware description languages (HDL), such as VHDL, used in the project, or the less well-known Verilog, can be used for this type of circuits [5]. The use of such a developed VLSI (Very-Large-Scale Integration) technology in the project allowed to place the entire processing system in a single reprogrammable chip. The development of the thermal imaging camera in this way allowed to reduce the size, cost and power consumption of the system.

Due to the small dimensions of the developed system, $25 \mathrm{~mm} \times 39 \mathrm{~mm}$, the camera will be ultimately placed in the

https://www.lynred.com/ 
drone. In order to improve the quality of the thermal image, bicubic interpolation and one-point non-uniformity correction (NUC) were implemented. Assuming, in accordance with the technical documentation of the detector pitch in equal to $34 \mathrm{\mu m}$ and focal length of the lens used is $\mathrm{f}=1.9 \mathrm{~mm}$, the obtained IFOV $\approx 18$ mrad. In practice, this means that at a distance of 1 meter, a single pixel "sees" a rectangle with a side of $18 \mathrm{~mm}$. It denotes that from this distance the camera cannot distinguish objects smaller than this value. For a camera of the size of the $80 \times 80$ matrix, we define the horizontal (HFOV) and vertical (VFOV) resolution ${ }^{2}$.

In order to enlarge the possible field of applications, the developed IR system can be equipped with different communication interfaces as shown in Fig. 1.

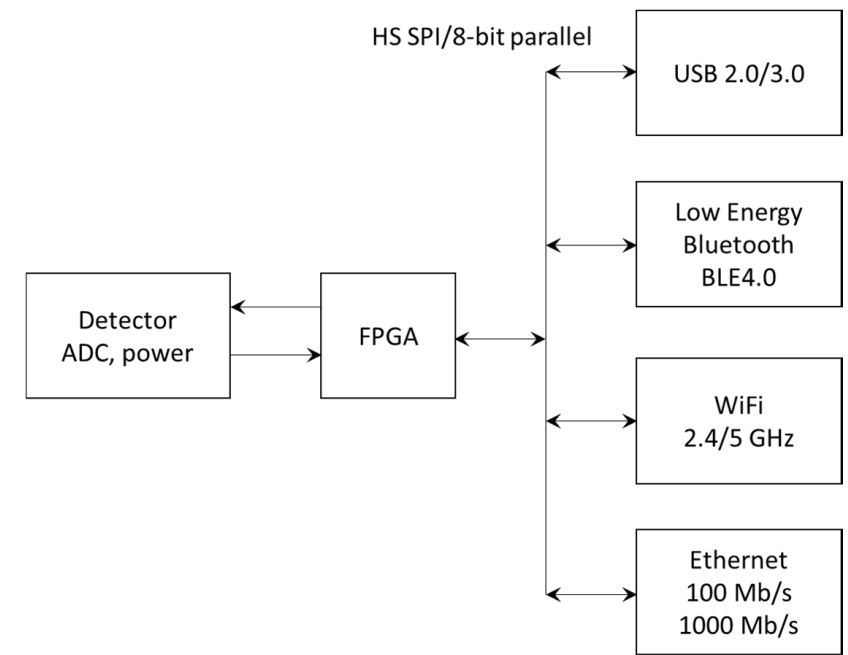

Fig. 1. The block diagram different configurations of low-cost IR bolometric system equipped with Micro80Gen2

Rys. 1. Schemat blokowy rożnych konfiguracji

systemu termowizyjnego o niskim koszcie produkcji z detektorem Micro80Gen2
The work presented in this paper has been done within the framework of master thesis during one diploma semester in the Institute of Electronics, Lodz University of Technology [9].

\section{Hardware development}

The typical bolometer detector is a square and rectangular matrix of bolometers connected internally to a readout circuit. The readout circuit integrates signals from each row of the matrix sequentially one by one. It contains transconductance amplifiers simultaneously integrating signals for all detectors of each row. The entire analog part of the detector is supervised by a digital controller to serialize the signals from each detector and generate sync pulses. The recently developed low-resolution bolometric detectors integrate a 14-bit $\mathrm{ADC}^{1}$. This simplifies the electronics of the camera and reduces external noise that can affect the analogue part made of high impedance sensors.

The electronics of the camera developed is equipped with two main elements: a digital controller integrated in $\mathrm{FPGA}^{3}$ and a communication chip that can be exchanged accordingly the application requirement (Fig. 1). In the system presented in this paper, the interface USB $2.0 \mathrm{HS}^{4}$ is implemented allowing the transmission at the speed up to $480 \mathrm{Mb} / \mathrm{s}$. One of the main advantage of such an architecture is the possibility of a direct connection to any mobile system (Fig. 2).

The FPGA integrates the entire glue logic generating required control signals and synchronising the scanning process in the detector and communication in the USB interface. Such a solution guarantees the simplicity of the system and low power consumption. The digital controller of the camera operates on the basis of state machines architecture. Two main digital circuits

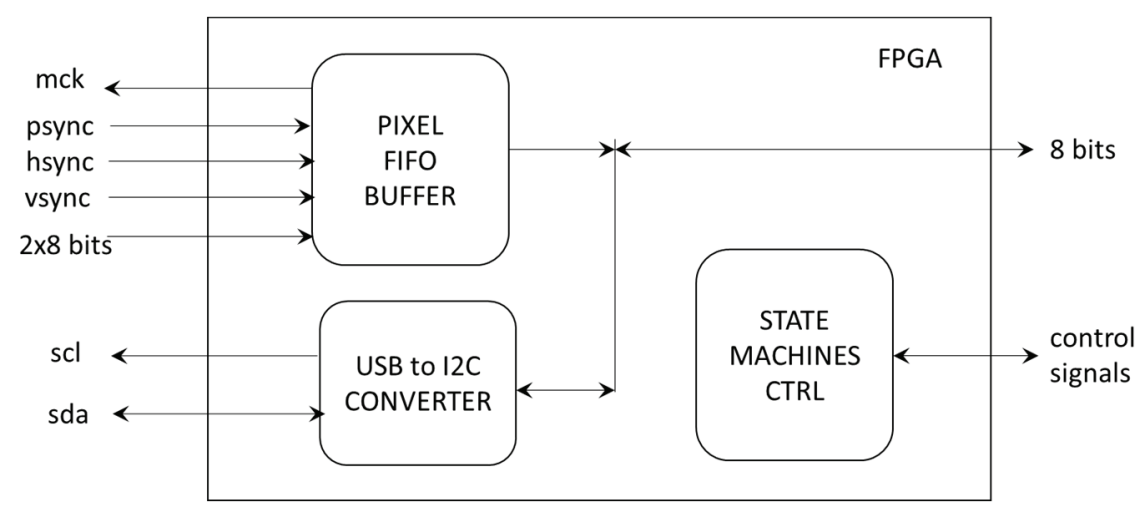

Fig. 3. The block diagram of the digital system integrated in a FPGA

Rys. 3. Schemat blokowy system cyfrowego zintegrowanego w układzie FPGA

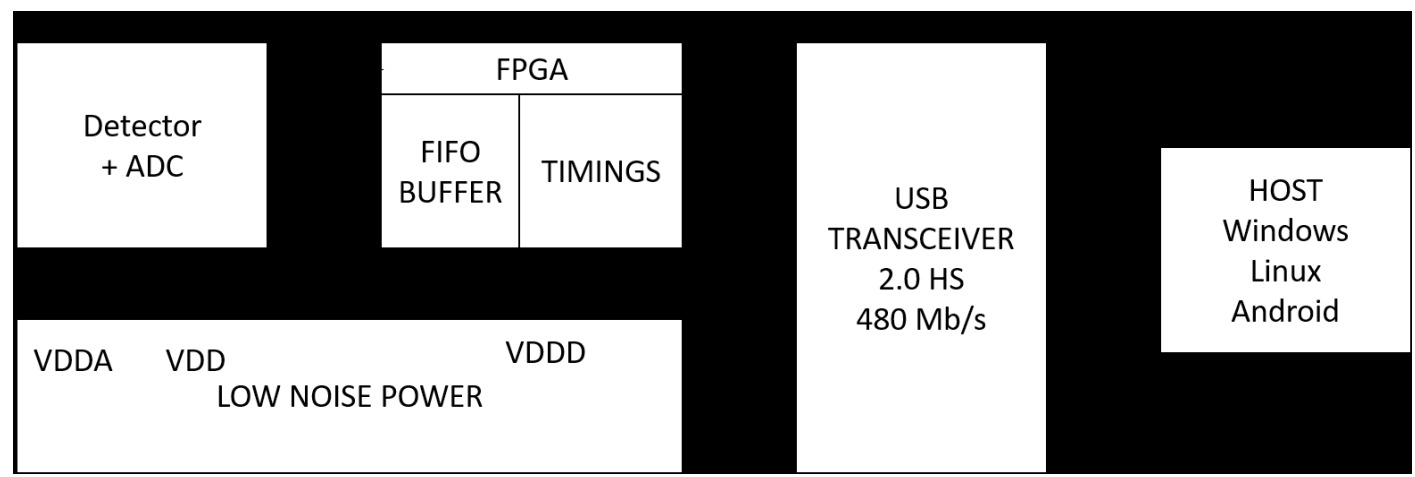

Fig. 2. The block diagram of electronic system of the developed camera

Rys. 2. Schemat blokowy elektronicznego systemu zaprojektowanej kamery termowizyjnej 


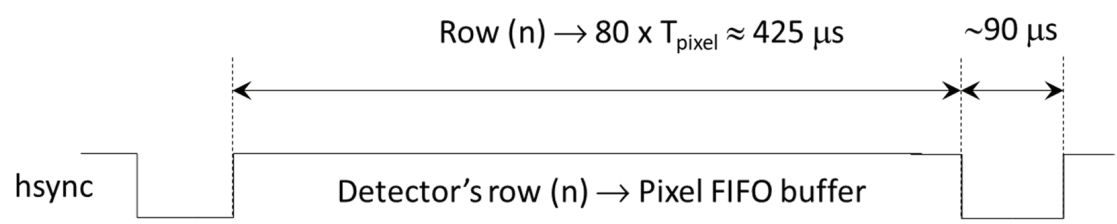

\section{Pixel FIFO buffer $\rightarrow$ USB FIFO}

Fig. 4. Time sharing between scanning the thermal data and transmission to a HOST using USB channel Rys. 4. Podział czasu na skanowanie sceny w detektorze i transmisję obrazu do komputera nadrzędnego

w kanale USB

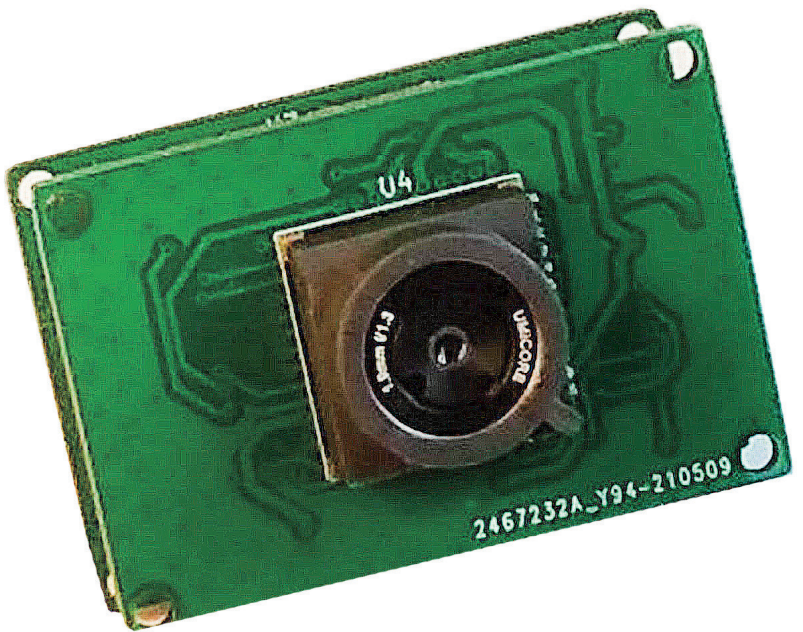

Fig. 5. Developed $80 \times 80$ bolometric camera $\mu \mathrm{IR} 80$

Rys. 5. Zaprojektowana kamera termowizyjna z matrycą $80 \times 80$ sensorów

were implemented in the FPGA: one-line fast RAM based FIFO buffer and bidirectional USB to $\mathrm{I}^{2} \mathrm{C}$ converter (Fig. 3). The presented solution uses the SPARTAN6 FPGA system. Optionally, to reduce power consumption, it can be replaced with a CPLD component, e.g. one of the COOLRUNNER family ${ }^{3}$. The firmware was implemented using VHDL language environment ISE Design Suite ${ }^{5}$.

Low-resolution IR camera development ensures the real-time full-frame transmission of the image sequence to any HOST. There are 160 bytes to transmit form each row of the bolometer matrix. This can easily be done in the "dead time" between the lines when scanning the bolometer matrix (Fig. 4). The proposed system works with the use of double data buffering using two FIFOs, one in the FPGA and the other in the USB chip. It simplifies the synchronisation two asynchronous processes: scanning in the detector and transmission through the USB channel.

The developed IR camera works with an integration time of $\mathrm{t}_{\text {int }}=85.25 \mu \mathrm{s}$ and enables transmission and refreshing of images at a frequency of $24 \mathrm{~Hz}$. The frame rate can be easily increased up to $50 \mathrm{~Hz}$. There is a fixed focal-length optics with the effective focal length equal to $\mathrm{f}=1.9 \mathrm{~mm}$, the radiometric $\mathrm{f}$-number $\mathrm{f} / 1.2$, transmission wavelength $\lambda \in(8-12) \mu \mathrm{m}$ and the field of view $\mathrm{FOV}=90^{\circ} \times 90^{\circ}$. Two-board sandwich-PCB camera developed $\mu \operatorname{IR} 80$ is presented in Fig. 5 .

\section{Micro80imager software}

In order to run the camera, the software Micro80imager was written in C\# language using Visual Studio 2012 environment $^{6}$. It implements camera setup with appropriate power and signal start-up. One-point non-uniformity correction (NUC)

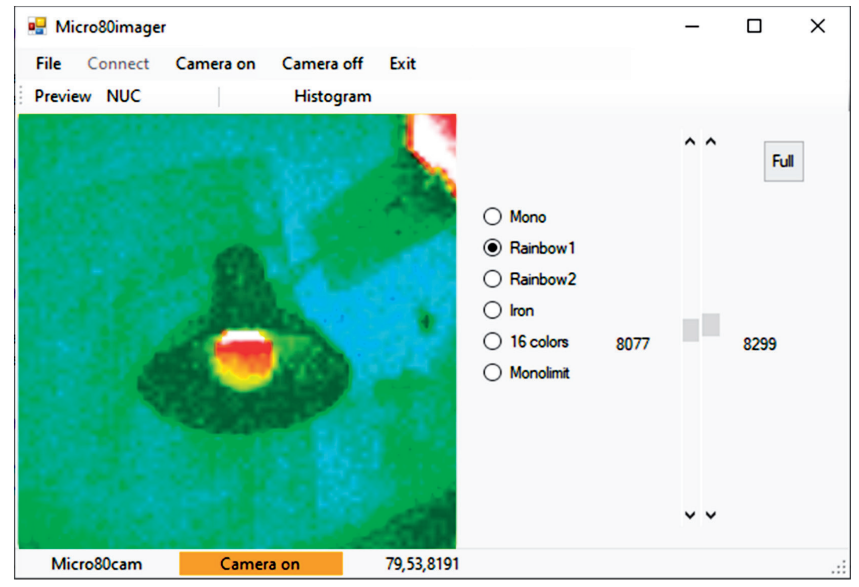

Fig. 6. Screen of the Micro80imager application

Rys. 6. Główne okno aplikacji Micro80imager

is also made on the level of end-user application. The communication is realised in the form of simple command-response principle, using the commands such as: nuc, get image, camera on/off, etc. Once image is in the computer memory, the simple image processing can be performed. At the first stage of the research the following functions are implemented: false colour assignment (palettes), histogram calculation, level and range of displayed image adjustment, statistical measures calculation, such as mean value and standard deviation and pixel value readout at any position of the cursor. The main window of Micro80imager is shown in Fig. 6.

Some measures of the camera's performance were estimated with the help of the prepared software. First, the raw image histogram was computed before the non-uniformity correction. It displays both the variability of the sensor characteristics and the location of bad pixels in the matrix (Fig. 7). It is noticeable, the operability of the system is high because only one bad pixel exists there.

Figure 8 shows imaging of a uniform scene after performing a one-point NUC. One can clearly see that the pixel non-uniformity is significantly reduced. Quantitatively, the quality of NUC can be expressed by calculating the standard deviation stdev. For a raw image, stddev $=207.05$, and for the corrected image, stddev $=2.81$.

In order to evaluate the selected parameters and evaluate the performance of the camera, it was placed in a variable temperature chamber. The temperature was chosen from ambient temperature to $45^{\circ} \mathrm{C}$. In addition, the camera was in the refrigerator for a quarter of an hour and then a raw photo was taken. Figure 9 shows the histograms of the raw images of a uniform thermal scene for different ambient temperature in the range $10-45^{\circ} \mathrm{C}$. 

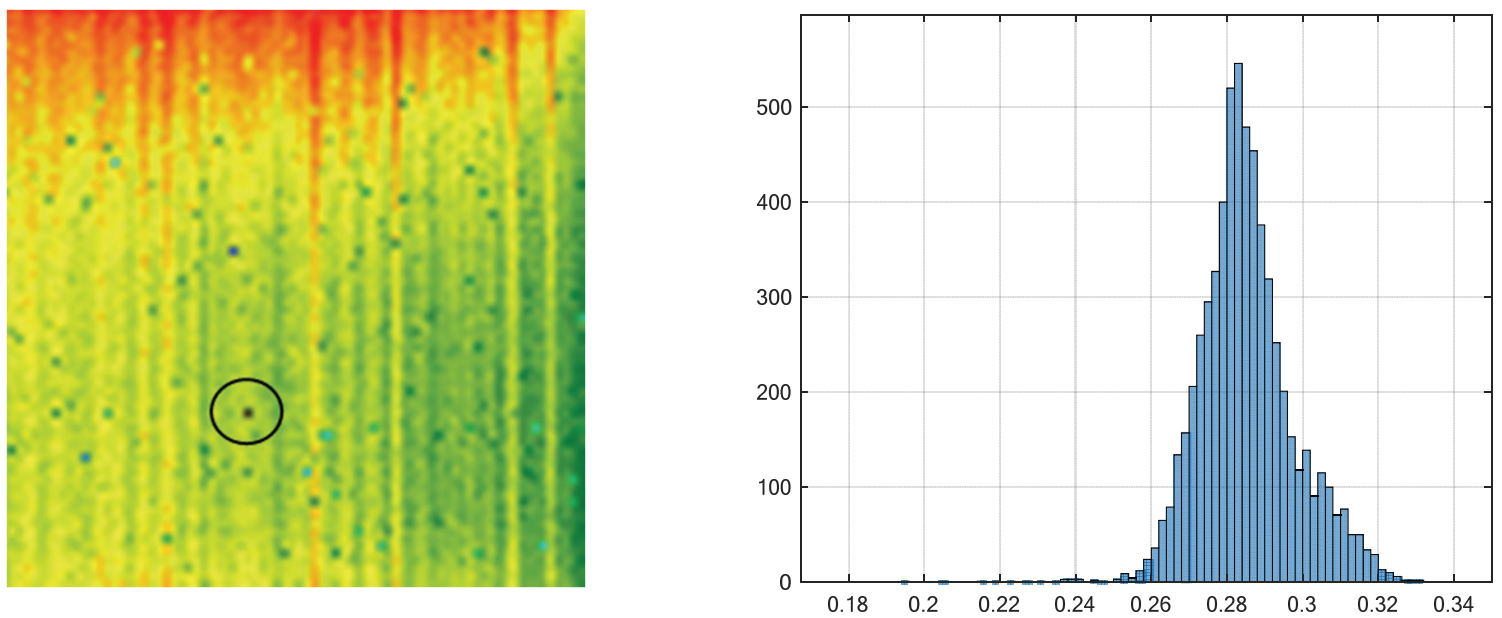

Fig. 7. Non-uniformity and histogram of pixel values for an IR image before non-uniformity correction with indication of the single bad pixel

Rys. 7. Niejednorodność (NU) oraz histogram obrazu termowizyjnego przed zastosowaniem 1-punktowej korekcji niejednorodności ze wskazaniem pojedynczego uszkodzonego piksela
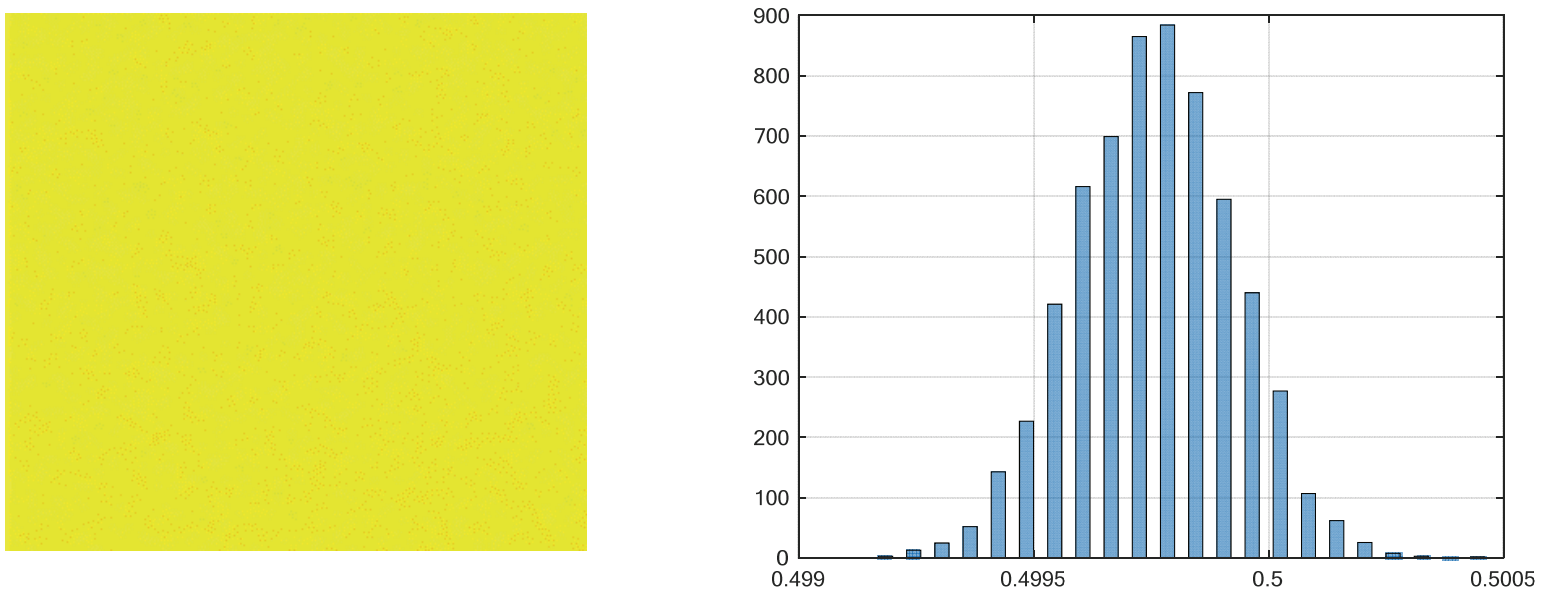

Fig. 8. An IR image and it histogram after one-point non-uniformity correction

Rys. 8. Obraz termowizyjny oraz histogram po zastosowaniu 1. punktowej korekcji niejednorodności matrycy detektora

a)

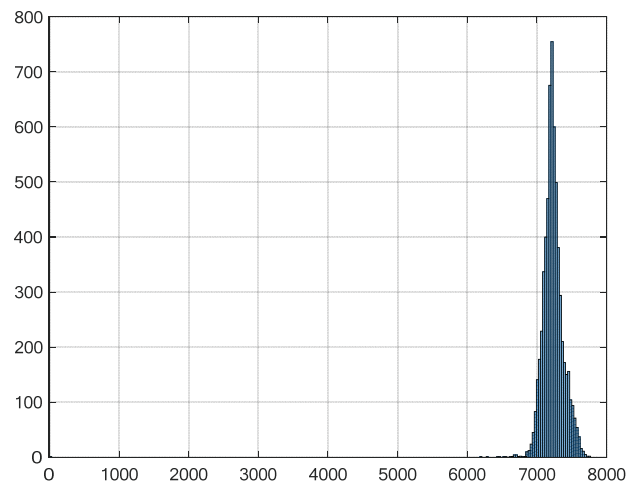

c)

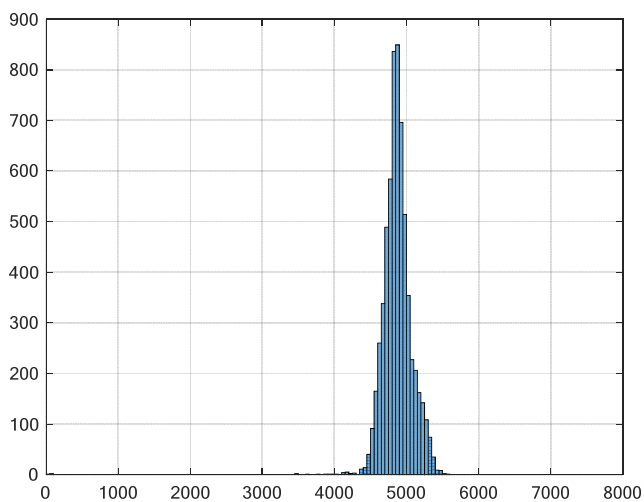

b)

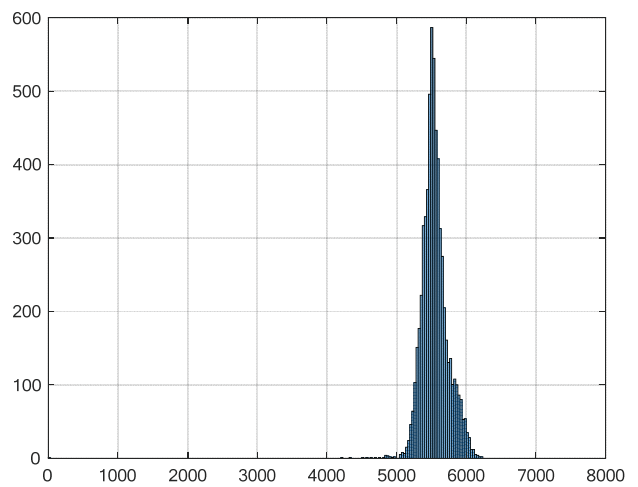

d)

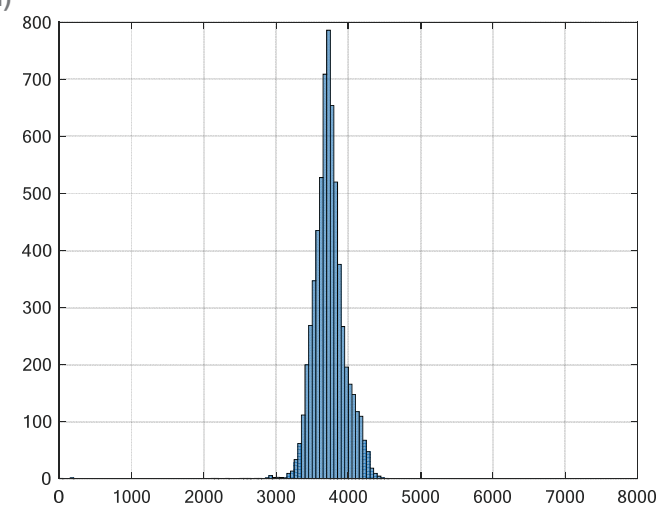

Fig. 9. Histograms showing the disparity of pixels signals for different ambient temperature $\mathrm{T}$ : a) $10^{\circ} \mathrm{C}$, b) $27^{\circ} \mathrm{C}$, c) $35^{\circ} \mathrm{C}$, d) $45^{\circ} \mathrm{C}$

Rys. 9. Histogramy ilustrujące rozrzut sygnału detektora dla różnych wartości temperatury otoczenia $\mathrm{T}_{2}$ : a) $10^{\circ} \mathrm{C}$, b) $\left.27^{\circ} \mathrm{C}, \mathrm{c}\right) 35^{\circ} \mathrm{C}$, d) $45^{\circ} \mathrm{C}$ 


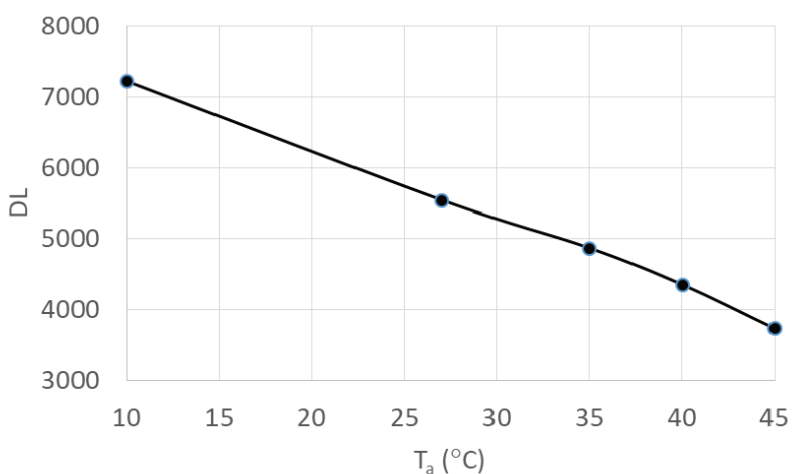

Fig. 10. Mean value of the raw images generated by the developed camera $\mu \mathrm{IR} 80$ for varying ambient temperature

Rys. 10. Wartość średnia surowego obrazu wygenerowanego przez zaprojektowaną kamerę termowizyjną $\mu \mathrm{IR} 80$ dla różnych wartości temperatury otoczenia

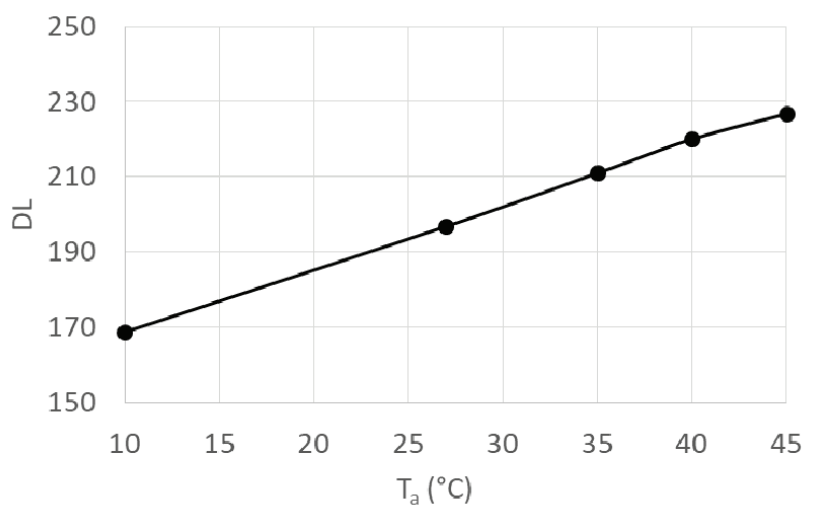

Fig. 11. Standard deviation of the raw images generated by the developed camera $\mu \mathrm{IR} 80$ for varying ambient temperature Rys. 11. Odchylenie standardowe surowego obrazu wygenerowanego przez zaprojektowaną kamerę termowizyjną $\mu \mathrm{IR} 80$ dla różnych wartości temperatury otoczenia

Raw image histograms allow to estimate camera drift due to changing ambient temperature. Additionally, the standard deviation of the recorded images shows the dependence of the non-uniformity of the detector matrix caused by changing environmental conditions. As you can see, the average value of signals generated by all sensors decreases with increasing ambient temperature (Table 1, Fig. 10). This is the influence of the "blind" compensating detector, which is part of the readout circuit and is connected to the detector.

However, the standard deviation of raw images slightly increases with the ambient temperature (Table 1, Fig. 11). This leads to the practical conclusion that rapid changes in ambient temperature must result in an immediate one-point correction.

Table 1. Mean values and standard deviations of raw images for different ambient temperature $\mathrm{T}$.

Tabela 1. Wartości średnie i odchylenia standardowe surowych obrazów termowizyjnych dla różnych wartości temperatury otoczenia $T_{a}$

\begin{tabular}{|c|c|c|}
\cline { 2 - 3 } \multicolumn{1}{c|}{} & mean (DL) & stdev (DL) \\
\hline $\mathrm{T}_{\mathrm{a}}=10^{\circ} \mathrm{C}$ & 7229.45 & 168.76 \\
\hline $\mathrm{T}_{\mathrm{a}}=27^{\circ} \mathrm{C}$ & 5548.23 & 196.87 \\
\hline $\mathrm{T}_{\mathrm{a}}=35^{\circ} \mathrm{C}$ & 4873.21 & 214.98 \\
\hline $\mathrm{T}_{\mathrm{a}}=40^{\circ} \mathrm{C}$ & 4354.47 & 222.02 \\
\hline $\mathrm{T}_{\mathrm{a}}=45^{\circ} \mathrm{C}$ & 3732.94 & 228.72 \\
\hline
\end{tabular}

Finally, an example of an infrared image taken from a distance of about $60 \mathrm{~cm}$ is shown in Fig. 12. Displaying of low-resolution infrared images requires interpolation. The images in Fig. 12 are interpolated with scale 4 to a resolution of $320 \mathrm{px} \times 320 \mathrm{px}$. Such interpolation must be implemented in the camera firmware and should work in real time. It requires sufficient computing power and may increase energy consumption. Therefore it is recommended to implement the interpolation in an external application.

\section{Conclusions}

The article presents a thermal imaging camera with low power consumption and low production cost. There are plans to connect a thermal imaging camera to a drone and/or to a mobile phone. It is possible that the camera will also use $5 \mathrm{G}$ technology. This presented solution will certainly affect safety in many applications and will enlarge the field of possible applications. The additional image processing can be implemented to improve the quality of images generated.
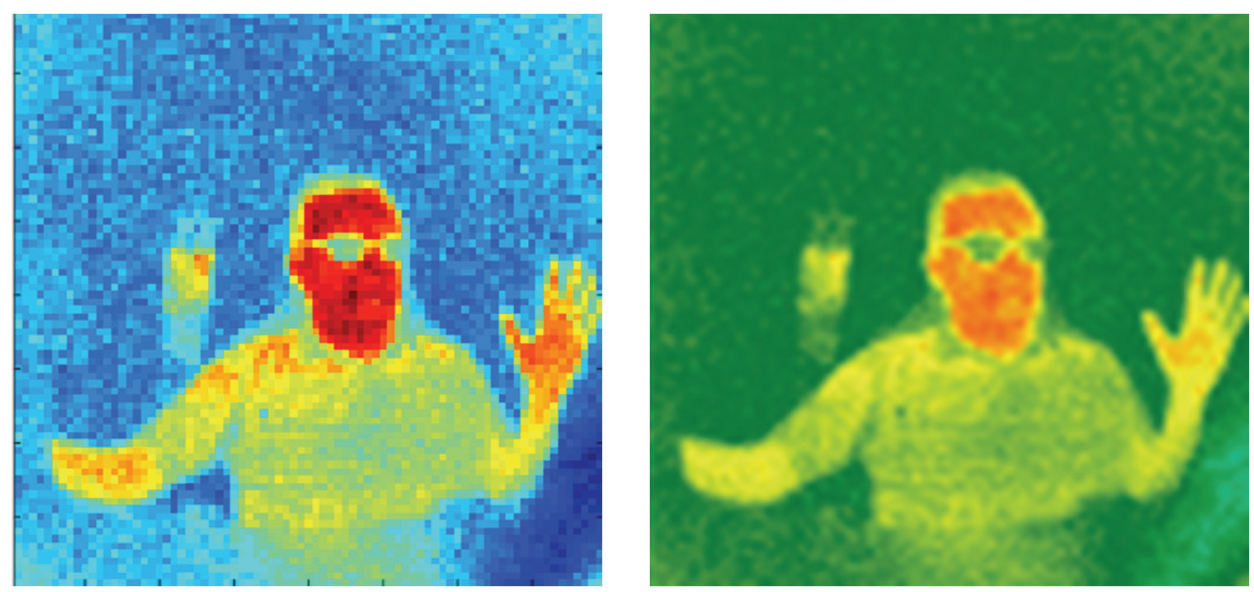

Fig. 12. Thermal images of $320 \mathrm{px} \times 320 \mathrm{px}$ resolution after NN (Nearest Neighbour) and the bicubic interpolation $(\times 4)$ of the original $80 \times 80$ image Rys. 12. Obrazy termowizyjne o rozdzielczości 320 px × 320 px po interpolacji metodą najbliższego sąsiada oraz interpolacji bikubicznej oryginalnego obrazu o rozmiarze $80 \times 80$ sensorów 


\section{References}

1. Więcek B., Pacholski K., Olbrycht K., Strąkowski R., Kałuża M., Borecki M., Wittchen W., Termografia i spektrometria w podczerwieni, WNT, Warszawa 2017.

2. Więcek B., De Mey G., Termowizja w podczerwieni. Podstawy $i$ zastosowania Łódź: Wydawnictwo PAK, 2011.

3. Minkina W., Dudzik S., Infrared Thermography: Errors and Uncertainties, Wiley, 2009.

4. Maldague X.P., Theory and Practice of Infrared Technology for Nondestructive Testing. Wiley, 2001.

5. Kania D., Uktady logiki programowalnej. Podstawy syntezy $i$ sposoby odwzorowania technologicznego, Wydawnictwo Naukowe PWN, Warszawa 2012.
6. Gołda A., Kos A., Projektowanie układów scalonych CMOS, Wydawnictwa Komunikacji i Łączności, Warszawa 2010.

7. Minkina A., Wild A., Rutkowski P., Podstawy pomiarów termowizyjnych. Cz. I - Istota termowizji i historia jej rozwoju, „Pomiary Automatyka Kontrola”, 2000, R. 46, Nr 1, 7-10.

8. Minkina W., Pomiary termowizyjne - przyrzady i metody, Wydawnictwo Politechniki Częstochowskiej, 2004.

9. Urbaś S., Development of infrared cameras (Projektowanie kamer termowizyjnych), M.Sc. diploma thesis, Institute of Electronics, Lodz University of Technology, academic year $2020 / 2021$

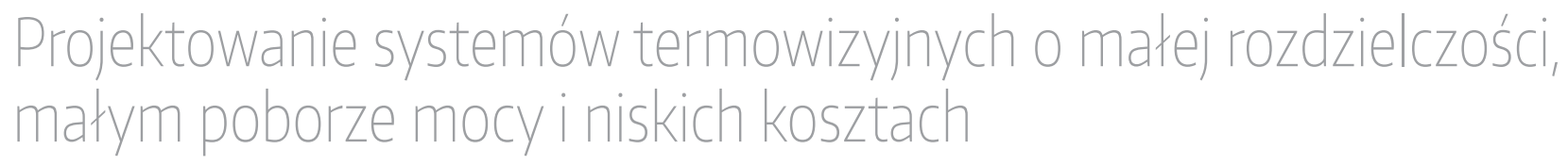

Streszczenie: w artykule przedstawiono budowę i oprogramowanie kamery termowizyjnej $\mu \mathrm{IR} 80$ o niskim poborze mocy. Kamera wyposażona została w mikrobolometryczny detektor podczerwieni 80 × 80 - Micro80Gen2, który pochłania promieniowanie podczerwone w długofalowym zakresie spektralnym LWIR (8-12 $\mu \mathrm{m})$. Cyfrowa część układu została zintegrowana w układzie FPGA z rodziny Spartan 6. W celu odczytu i wyświetlenia obrazu termalnego, napisane zostało oprogramowanie na platformie .NetFramework 3.1. Dodatkowo zaimplementowano 1-punktową korekcję niejednorodności matrycy detektora (NUC) oraz podstawowe algorytmy przetwarzania obrazów, np. wyznaczanie histogramu, zmianę zakresu i interpolację bikubiczną. Ze względu na niski koszt oraz niewielkie wymiary i masę, przedstawiona kamera termowizyjna może znaleźć zastosowanie w wielu dziedzinach począwszy od monitorowania otoczenia przy pomocy bezzałogowego statku powietrznego (UAV), po zastosowania w przemyśle, energetyce i medycynie.

Słowa kluczowe: detektor bolometryczny, kamera termowizyjna, projektowanie systemu, FPGA

\section{Prof. Bogusław Więcek, PhD DSc}

boguslaw.wiecek@p.lodz.pl

ORCID: 0000-0002-5003-1687

Bogusław Wieccek is the head of Electronic Circuit and Thermography Division in the Institute of Electronics where he has been working for more than 40 years. His scientific interests are: heat transfer modelling, industrial and biomedical applications of IR thermography and IR system modelling and developments. He is responsible for organizing the largest conference on thermography in Central and Easter Europe every two years "Infrared thermography and thermometry - TTP".

\section{Sebastian Urbaś, MSc Eng.}

seurbas@gmail.com ORCID: 0000-0002-7699-5425

Sebastian Urbaś graduated from the Faculty of Electrical Engineering, Electronics, Computer Science and Automation at the Lodz University of Technology (LUT) in 2021. He holds a master's degree in electronics engineering (LUT). He finished the College of Social and Media Culture in Toruń (2019) and received bachelor's degree in computer science (IT engineering) as well as the journalism diploma. There he completed postgraduate studies in the field of project management (MBA Executive). The main areas of interest are embedded electronics, computer thermography, signal and image processing and development of IR systems. 